\title{
Bacteremia in the red blood cells obtained from the cell saver in patients submitted to heart surgery
}

Manuel Luque-Oliveros ${ }^{1}$
(1) https://orcid.org/0000-0003-4346-617X

${ }^{1}$ Universidad de Sevilla, Sevilla, Espanha.
Objective: to determine the microbiological characteristics of the red blood cells obtained with the cell saver in heart surgery patients on an extra-body circuit. Method: a crosssectional and descriptive study conducted with 358 patients scheduled for heart surgery where the saver was used. Sociodemographic variables were collected, as well as from the saver and of the microbial identification in the reinfusion bag proceeding from the cell saver. Informed consent performed. Results: of the 170 GRAM+ bacteria isolations, the most frequent species were Staphylococcus epidermidis in $69 \%(n=138)$ of the cases and Streptococcus sanguinis with a report of $10 \%(n=20)$. Significant differences were found in the Staphylococcus epidermidis strain in patients with a Body Mass Index $\geq 25(p=0.002)$ submitted to valve surgery $(p=0.001)$. Vancomycin was the antimicrobial which resisted the Staphylococcus epidermidis strain with a minimum inhibitory concentration of $>16 \mu \mathrm{g} / \mathrm{ml}$. Conclusion: the microbiological characteristics of the red blood cells obtained after processing autologic blood recovered with the cell saver during heart surgery are of GRAM+ bacterial origin, the most isolated species being Staphylococcus epidermidis. Consequently, in order to reduce the presence of these GRAM+ cocci, an antibiotic should be added to the cell saver reservoir, according to a previously established protocol.

Descriptors: Blood Transfusion, Autologous; Bacteremia; Thoracic Surgery; Erythrocytes; Extracorporeal Circulation; Operating Room Nursing.

\section{How to cite this article}

Luque-Oliveros M. Bacteremia in the red blood cells obtained from the cell saver in patients submitted to heart surgery. Rev. Latino-Am. Enfermagem. 2020;28:e3337. [Access DOI: http://dx.doi.org/10.1590/1518-8345.3092.3337. 


\section{Introduction}

Invasive infections during heart surgery have been reported internationally ${ }^{(1)}$; in fact, bacterial contamination outbreaks have been described recently in the cooling-heating devices used to regulate the patient's blood temperature during the extra-body flow through the closed water circuits ${ }^{(2)}$. New studies indicate the presence of other bacterial colonizations in the membrane oxygenators of the extra-body circuit itself, which compromises bacterial re-circulation in the patients during the time the extra-body machine is used ${ }^{(3-8)}$. Additionally, knowing that heart surgery is the medical specialty which consumes the most blood products $^{(9)}$, the cell saver (CS) is used, a device which recovers blood losses from the surgical field and from the residual volume of the extra-body circuit to submit it to a "cleaning" process, obtaining a certain volume of red blood cells which is reinfused into the patient (reinfusion bag). In this device, bacterial growth was detected in $85 \%$ of the samples of recovered blood(10) and in the samples of red blood cells to reinfuse GRAM+ bacterial commensals(11), and even in other surgical procedures like traumatologic ones (scoliose in Pediatrics), where the CS was also used and the same commensals were detected in the re-infusion bag, but of the staphylococcus genus(12).

The presence of bacteria in the saver, both in its recovery process and in its reinfusion phase, supposes a potential infection risk for the patient during the surgical procedure since these devices lack anti-bacterial protection ${ }^{(13)}$. This fact gains importance because the presence of bacteremia in the patient is associated with vascular accesses, prolonged hospitalizations, treatments in intensive care units, and administration of multiple broad-range antibiotics where immunosuppresion is the most important comorbidity and where mortality is significant ${ }^{(14)}$.

Currently, considering the weight of the existing evidence and in the context of heart surgery, there is little evidence on the different types of bacteremia that can be contained in the red blood cell bag which is reinfused into the patient, proceeding from the cell saver, reason why we set ourselves the objective of determining the microbiological characteristics of the red blood cells obtained with the cell saver in the heart surgery patient on an extra-body circuit.

\section{Method}

A cross-sectional and descriptive study conducted with patients scheduled for the heart surgery service in the period from May $1^{\text {st }}$ to October $1^{\text {st }}, 2017$, with its data obtained from the managerial request for the surgical demand, in Sevilla, Spain. Of all the patients submitted to heart surgery on an extra-body circuit with the use of the C.A.T.S ${ }^{\circledR}$ (Continuous Autologous Autotransfusion System, Fresenius) cell saver, those over 18 years of age and who accepted to participate in the study after verbal introduction and explanation of the informed consent were included. Patients were excluded when the saver was not used according to the indications of the scheduled surgery. The exclusion criteria also included immuno-suppressed patients (infectious-contagious or carcinogenic diseases; for being contraindication measures to the use of the saver), and patients on anti-microbial therapy because it creates a bias in data collection. Before the surgery, the patients were conventionally and uniformly prepared: continuous hemodynamic monitoring, with general anesthesia in its three phases (induction, maintenance, and recovery) with the same drugs at a dose proportional to the patient's weight and height.

The surgical approach was conducted homogeneously in all the patients: sternal dissection and opening by means of longitudinal sternotomy, cannulation of big blood vessels, similar perfusion protocols and extra-body flow techniques, and with similar surgical techniques employed during the surgery.

After finishing the surgery, the hemostasis of all the anastomosis was verified, and coagulation was reverted by means of protamine sulphate with a $1: 1$ ratio with heparin, where all the extubated patients were given the fast track protocol inherent to the post-anesthetic service.

The preparation and management of the saver in all the patients was undifferentiated: for circuit priming and purge $3,000 \mathrm{~mL}$ of crystalloids were used, combined with 30,000 IU of sodium heparin to avoid coagulation. The surgical field blood losses were recovered with a suction vacuum system which can be regulated to $-20 \mathrm{~cm} \mathrm{H}_{2} \mathrm{O}$, as well as those from the residual volume in the extra-body circuit $^{(15)}$, where it passed through a $25 \mu \mathrm{m}$ filter into a reservoir and, after finishing the surgery, its processing or the wash cycle began to obtain the red blood cell bag which was reinfused into the patient. The perfusionist herself assembled and purged the saver.

The operating room conditioning (access and walking aisles, construction characteristics, medicinal gases, thermal isolation, safety conditions, equipment, and ventilation systems) complies with the necessary requirements for asepsis inherent to the type and risk level of the intervention. In addition, general inspections are performed in the operating room to detect environmental contamination according to the current standards. 
The hospital's Microbiology Service worked with the Becton Drive Bactec ${ }^{\mathrm{TM}} 960$ bacterial automated system to measure $\mathrm{CO}_{2}$ production from microbiologically active micro-organisms by means of spectrophotometric methods or fluorescence, where each vial is controlled continuously and detection is external; as the vials are not opened, the possibility of cross-contamination is eliminated. For microbial identification, bacterial phenotypic identification techniques were carried out under a seriated microbiological culture of red blood cells proceeding from the saver reinfusion bag. For the isolation and identification of the pathogen agent, $20 \mathrm{~mL}$ of red blood cells were previously extracted (after finishing the entire wash cycle and before reinfusion into the patient), where the first $10 \mathrm{~mL}$ were introduced in an anaerobics vial and the remaining $10 \mathrm{~mL}$ in an aerobics vial, performing the inversion technique. In the identification process of the bacterial strain, its morphology, growth, biochemical, and metabolic properties where observed and, when feasible, the involved micro-organism was identified. The porter himself sent the vials, and he employed asepsis techniques during the transfer, the send-receive time not exceeding 8 minutes.

The studied variables were; age, gender, scheduled surgical procedure, surgery time, body mass index, collected from the patient's clinical record; recovered blood volume in the reservoir, erythrocyte concentrate volume, discarded remaining volume, and processing time, obtained through the information available in the CS; GRAM+ cocci, GRAM- cocci, GRAM+ bacillus, and GRAM- bacillus with isolation in their diversity, collected through microbiology. All collected data were recorded in our ad hoc document.

For data exploitation, the SPSS for Windows statistical program was used, expressing the categorical variables by means of percentages and of relative and absolute frequencies.

Finally, the continuous variables are presented through central tendency and standard deviation measures. Pearson's chi-square test and Fisher's exact test were used in the categorical variables, as it was found pertinent. Finally, the Student's t test was applied to the continuous variables to determine whether there were statistically significant differences. A significant $p$ value $<0.05$ and a $3 \%$ sampling error were set.

The studied complied with the principles set forth in the Declaration of Helsinki, in Organic Law of Personal Data Protection No. 15/1999 of December $13^{\text {th }}$, and in Royal Decree No. 1,720/2007, which develops it. All the patients were informed both verbally and through the informed consent form. This study obtained the formal approval of the hospital's Commission on Ethics and Clinical Research.

\section{Results}

Of the total $100 \%(n=358)$ of the patients scheduled for heart surgery, 56.1\% $(n=201)$ were selected for meeting the inclusion criteria, and $43.9 \%(n=157)$ were excluded because, in $41.7 \%(n=149)$ of the cases, the CS was not used, and because $2.2 \%(n=8)$ did not sign the informed consent form. The characteristics of the patients were the following: mean age of 65 years old, mainly men (74\%) with a Body Mass Index of 24.2, the aortic valve surgery being the most common (65\%) according to Table 1 . The surgical times were the following: aortic valve, 242 minutes, tricuspid valve, 270 minutes, mitral valve, 260 minutes, and coronary bypass, 334 minutes.

Table 1 - Characteristics of the patients (201) included in the study. Seville, Spain, 2017

\begin{tabular}{lcc}
\hline \multicolumn{1}{c}{ Variable } & Mean Fr (\%)* & $\begin{array}{c}\text { Standard } \\
\text { deviation }\end{array}$ \\
\hline Age (years) & 65 & 8.9 \\
30 to 45 & $7(3.5)$ & \\
46 to 65 & $143(71.1)$ & \\
$>65$ & $51(25.4)$ & \\
Gender & & \\
Male & $149(74.1)$ & \\
Female & $52(25.9)$ \\
Body Mass Index & 24 \\
Low weight <18.5 & $1(0.5)$ \\
Normal weight 18.5-24.9 & $124(61.2)$ \\
Overweight 25 - 29.9 & $76(37.3)$ \\
Obese >30 & $2(1)$ \\
Scheduled surgery & \\
Aortic valve & $131(65)$ \\
Tricuspid valve & $2(1)$ \\
Mitral valve & $28(14)$ \\
Coronary bypass & $40(20)$ \\
1 vessel & $19(9)$ \\
2 vessels & $18(9.5)$ \\
3 vessels & $3(1.5)$ & \\
\hline Fr (\%) $=$ Frequency (percentages) &
\end{tabular}

Regarding the cell saver values, the following figures were obtained: mean volume of $2,163 \mathrm{ml}$ of recovered blood (Standard Deviation $=588.67), 602 \mathrm{ml}$ of red blood concentrates (Standard Deviation $=177.49$ ), 4,719 ml of discarded remnants (Standard Deviation $=1,282.01$ ) in a mean processing time of 25 minutes (Standard deviation $=5.83$ ).

With respect to the microbial identification, the coagulase-negative GRAM+ bacteria were the most frequently isolated in the Staphylococcus epidermidis species, with $69 \%(n=138)$ of the cases, followed by 
Streptococcus sanguínis (S. viridans) with a report of $10 \%(n=20)$ according to Table 2.

Table 2 - Bacterial species identified in $85 \%$ of the red blood cell reinfusion bag proceeding from the cell saver. Seville, Spain, 2017

\begin{tabular}{lc}
\hline \multicolumn{1}{c}{ Bacterial group } & $\operatorname{Fr}(\%)^{*}$ \\
\hline GRAM+ cocci & \\
Staphylococcus & $138(69)$ \\
epidermidis & $2(1)$ \\
haemolyticus & $4(2)$ \\
hominis & $2(1)$ \\
caprae & $2(1)$ \\
simulans & $2(1)$ \\
cohnii & \\
Streptococcus & $20(10)$ \\
sanguinis (viridans) & \\
GRAM- cocci & \\
GRAM+ bacillus & \\
Corynebacterium & \\
diphteroides & \\
GRAM- bacillus & \\
Bacteroides & \\
fragilis & \\
*Fr (\%) = Frequency (percentages) & \\
&
\end{tabular}

In the relation of the Staphylacoccus epidermidis strain according to the profile of the studied patient, statistically significant differences were found with respect to the Body Mass Index $(p=0.002)$ and to the surgical procedure performed $(p=0.001)$, according to Table 3 .

Table 3 - Relation of the presence of Staphylococcus epidermidis with different characteristics of the studied patient $(n=201)$. Seville, Spain, 2017

\begin{tabular}{lccc}
\hline \multicolumn{4}{c}{ Staphylococcus epidermidis } \\
\hline \multicolumn{1}{c}{ Variable } & $\begin{array}{c}\text { Yes (n=138) } \\
\text { Fr (\%) }\end{array}$ & $\begin{array}{c}\text { No }(\mathbf{n}=63) \\
\text { Fr (\%) }\end{array}$ & p \\
\hline Age (years) & $101(67.3)$ & $49(32.7)$ & $0.16^{*}$ \\
$<65$ & $37(72.5)$ & $14(27.5)$ & \\
$\geq 65$ & & & $0.31^{*}$ \\
Gender & $99(66.4)$ & $50(33.6)$ & \\
Male & $39(75)$ & $13(25)$ & \\
Female & & & \\
Body Mass Index & & & \\
$<25$ & $63(50.4)$ & $62(49.6)$ & \\
$\geq 25$ & $75(98.7)$ & $1(1.3)$ & \\
Surgery & & & $0.001^{\dagger}$ \\
Valve & $135(83.8)$ & $26(16.2)$ & \\
Bypass & $3(7.5)$ & $37(92.5)$ & \\
\hline
\end{tabular}

*Pearson's Chi-Square; ${ }^{+}$Fisher's Exact test. Significance level: $p<0.05$.
The antimicrobial which resisted the Staphylococcus epidermidis strain was Vancomycin, with a minimum inhibitory concentration of $>16 \mu \mathrm{g} / \mathrm{ml}$.

Table 4 - Antimicrobial sensitivity of Staphylococcus epidermidis. Seville, Spain, 2017

\begin{tabular}{lcc}
\hline Antimicrobials & $\begin{array}{c}\text { Sensitivity } \\
\left(\mathbf{S}^{*} / \mathbf{I}^{\dagger} / \mathbf{R}^{\ddagger}\right)\end{array}$ & $\begin{array}{c}\text { Minimum Inhibitory } \\
\text { Concentration }(\boldsymbol{\mu g} / \mathbf{m l})\end{array}$ \\
\hline Rifampycin & $\mathrm{S}$ & $<=0.015<=0.25$ \\
Daptomycin & $\mathrm{S}$ & $<=0.5$ \\
Tigecycline & $\mathrm{S}$ & $>16$ \\
Vancomycin & $\mathrm{R}$ & $<=8$ \\
Phosphomycin & $\mathrm{I}$ & $<=1$ \\
Linezolid & $\mathrm{S}$ & $>2$ \\
Methicillin & $\mathrm{R}$ & \\
\hline
\end{tabular}

*S = Sensitive; ${ }^{+} \mathrm{I}=$ Intermediate $;{ }^{\ddagger} \mathrm{R}=$ Resistant

\section{Discussion}

The study data expose the presence of bacteria in the red blood concentrates of the reinfusion bag, with a high report of coagulase-negative GRAM+ bacteria in their Staphylococcus epidermidis species composing part of the cutaneous and mucous flora, where their identification sets forth the following dilemma among the professionals: contamination or real bacteremia?

Currently, in developed countries the vast majority of intra-hospital microbiological isolations in blood are due to GRAM+ cocci, including those due to coagulase-negative Staphylococcus ${ }^{(16)}$ and, in some studies, it is the main cause of hospital bacteremia(17). In a study, coagulasenegative Staphylococcus was identified in the concentrate obtained from the saver in $54.2 \%$ of the cases, reason why it was pointed out that the use of this device is not the best option in surgery. However, this study lacks the inclusion of an extra-body circuit and does not even expose the different types of isolated micro-organisms in the saver, since it only focused on isolating one of them ${ }^{(12)}$.

Likewise, in other studies GRAM+ bacteria were detected by blood extraction from the patient, concluding the hetero-resistance to certain antibiotics ${ }^{(14,18)}$, but its results include only hospitalized (not surgical) patients, reason why its prevalence is not demonstrated in the context of heart surgery for not using the saver.

It is to be recalled that bacterial infections are the leading cause of mortality due to blood transfusions ${ }^{(19)}$, as confirmed by the data from a research study ${ }^{(20)}$, which verified a significantly higher infection risk in the patients treated with a liberal transfusion policy than in those treated with a restrictive strategy (12.7\% vs $10.6 \%)$. In this study it was concluded that a restrictive transfusion strategy for red blood cells was associated with a reduction in the infection risk (pneumonia, mediastinitis, infection of the surgical wound, and sepsis) if compared to the liberal transfusion strategy. However, they do not analyze its cause (type of originating bacteria) nor do 
they describe the type of red blood cell transfusion they perform, with the possibility of it being homologous or autologic, as the case of the saver.

In other studies(21), in 83 samples the presence of Staphylococcus epidermidis was identified, thus concluding that this strain could be susceptible to causing infections in the bloodstream. However, the isolations were performed in patients with neoplastic pathologies, and not in the context of heart surgery.

On the other hand, the report of a research study ${ }^{(22)}$ states that Staphylococcus epidermidis is a well-known etiology of the endocarditis of prosthetic valves, and the one emerging from native valve endocarditis where they have been successfully treated with antibiotic therapy like Vancomycin. We disagree with this author because, in the study, Vancomycin showed resistance to the same strain $>16 \mu \mathrm{g} / \mathrm{ml}$.

Recent studies show that adding Vancomycin to the wash serum of the CS itself is effective on bacterial contamination, allowing for its elimination (2) but, in these studies, the participants were scheduled for back spinal fusion surgery, did not use an extra-body circuit, and the study only determines the bacterial elimination in the saver reservoir without subsequently analyzing bacteremia in the red blood cell bag, as shown in our study.

We do agree with the studies which identified that Staphylococcus epidermidis was the most frequent micro-organism in heart surgery, where the unsaturation of different diagnostic and therapeutic measures taken by a multidisciplinary team had a favorable influence on the patients' prognosis(23). Other studies(24) show the same results. However, they did not determine the isolation source or the antimicrobial sensitive to the strain.

Despite the improvements in the surgical techniques, in the materials, and in the design of the devices, the associated infection is still a relatively frequent and serious complication. Another research study ${ }^{(25)}$ shows that the infection is generally produced during the surgery starting from the patient's cutaneous microbiota, when the micro-organisms colonize a device, grow on its surface forming a bio-layer which is determinant in the pathogenia of these infections, reason why we emphasize the importance of identifying the species in any isolation which is considered significant ${ }^{(26)}$ because GRAM+ cocci are increasingly involved in intra-hospital infections ${ }^{(27)}$.

Additionally, a recent multi-centric study conducted in 26 hospitals (PROBAC cohort) detected bacteremia episodes in the intra-cardiac devices due to GRAM+ cocci in $30.4 \%$ of the patients, a fact which undoubtedly evidences that the infection risk due to hematogenous seeding is present in these patients ${ }^{(28)}$, even with the possibility of triggering an infectious endocarditis (IE).

According to a new study, the origin of the IE episode could be attributed to diagnostic procedures in $10.52 \%$ of the cases, to intercurrent infectious processes in $42.11 \%$ of the cases, to other surgical procedures in $26.3 \%$ of the cases, and to unknown causes in $21.05 \%$ of the cases, with the need for surgical treatment in all the $\operatorname{cases}^{(29)}$. The fact that an IE is produced due to any of the aforementioned causes generates a considerable increase in the risk of the bacterial layer settling on the prosthetic materials, or of residual injuries and frequently on right cavities ${ }^{(30)}$, which becomes a serious form of the disease with high global mortality(29). Nevertheless, these researchers did not determine the source of the bacteremia, nor did they establish the elements or components of the possible infection focuses, which is necessary to establish a clinical suspicion prior to providing an early diagnosis and treatment to the patients.

Up to the present day, conventional therapies with antimicrobial agents are used to treat and prevent the associated infections; however, the professionals disagree on the origin of the cardiac patient's infections during the post-operative period, based on the existing data. Furthermore, recent research studies assert that, under certain conditions, the effectiveness and benefits for the patients from using the cell saver under extra-body circulation are ambiguous, with discrepancies among the studies or the patients ${ }^{(31)}$. Not to mention the current safety problems in cases of severe bacterial contamination where future studies will be needed to better determine how and when the cell saver is to be used, alongside with new blood conservation measures(32).

In this context, our study adds additional information on a possible infection focus to the scientific knowledge, incorporating isolation frequencies of bacterial strains in the red blood cell bag from the saver, which, in turn, allows acting accordingly with the available media.

This study has limitations: a) in its development because, for being conducted in a reference center, it could underestimate the prevalence of the isolation of the Staphylococcus epidermidis strain in the saver, and b) in its context, because in terms of clinical meaning, many times it is difficult to establish which strains can be harmless commensals and which invasive pathogens.

\section{Conclusion}

The microbiological characteristics of the red blood cells obtained after processing autologic blood recovered with the cell saver during heart surgery are of GRAM+ bacterial origin, the most isolated species being Staphylococcus epidermidis. Consequently, in order to reduce the presence of these GRAM+ cocci, an antibiotic should be added to the cell saver reservoir, according to a previously established protocol. 


\section{Acknowledgments}

To the Statistics expert. To my colleagues from Vigo for doing their utmost so that this study is published. Thank you.

\section{References}

1. Schreiber P, Kuster S, Hasse B, Bayard C, Ruegg C, Kohler P. Reemergence of Mycobacterium chimaera in heatercooler units despite intensified cleaning and disinfection protocol. Emerg Infect Dis. 2016 Oct;22(10):1830-3. doi: $10.3201 /$ eid2210.160925

2. Perez A, Gredilla E, de Vicente J, Navarro R, Gilsanz F. Vancomycin added to the wash solution of the cell-saver. Effect on bacterial contamination. Rev Esp Anestesiol Reanim. 2017 Apr;64(4):185-91. doi: 10.1016/j. redar.2016.10.002

3. Jaworski R, Naumiuk L, Paczkowski K, Formella D, Pek $\mathrm{R}$, Zielinski J. Mycobacterium chimaera-a new therat for cardiac surgical patients?. Kardiochir Torakochirurgica Pol. 2017 Mar;14(1):22-6. doi: 10.5114/kitp.2017.66925 4. Perkins K, Lawsin A, Hasan N, Strong M, Halpin A, Rodger $\mathrm{R}$, et al. Mycobacterium chimaera contamination of heater cooler devices used in cardiac surgery-United States. CDC. 2016 Oct;65(40):1117-8. doi: 10.15585/ mmwr.mm6540a6

5. Allen K, Yuh D, Schwartz S, Lange R, Hopkins $\mathrm{R}$, Bauer $\mathrm{K}$, et al. Nontuberculous mycobacterium infections associated with heater-cooler devices. Ann Thorac Sur. 2017 Oct;104(4):1237-42. doi: 10.1016/j. athoracsur.2017.04.067

6. Nielsen C, Winther CL, Thomsen PK, Andreasen JJ. Elimination of Mycobacterium chimaera in a heater cooler device used during on-pump cardiothoracic surgery. Perfusión. 2017 Sep;32(6):507-10. doi: $10.1177 / 0267659117700489$.

7. Sommerstein R, Rüegg C, Kohler P, Bloemberg G, Kuster $\mathrm{SP}$, Sax H. Transmission of Mycobacterium chimaera from heater-cooler units during cardiac surgery despite an ultraclean air ventilation system. Emerg Infect Dis. 2016 Jun;22(6):1008-13. doi: 10.3201/eid2206.160045

8. Kanamori H, Weber DJ, Rutala WA. HealthcareAssociated Outbreaks Associated with a Water Reservoir and Infection Prevention Strategies. Clin Infect Dis. 2016 Jun;62(11):1423-35. doi: 10.1093/cid/ciw122

9. Paniagua P. Transfusión sanguínea e infección después de la cirugía cardíaca. Rev Cir Cardiovasc. 2014 Sep;21(3):223-4. doi: 10.1016/j.circv.2014.02.006

10. Ishida T, Nakano K, Nakatani H, Gomi A. Bacteriological evaluation of the cardiac surgery enviroment accompanying hospital. Surg Today. 2006;36(6):504-7. doi: 10.1007/ s00595-006-3178
11. Bland LA, Villarino ME, Arduino MJ, McAllister SK, Gordon SM, Uyeda CT, et al. Bacteriologic and endotoxin analysis of salvaged blood used in autologous transfusions during cardiac operations. J Thorac Cardiovasc Surg. [Internet]. 1992 Mar [cited Jun 25, 2019];103(3):582-8. Available from: http://europepmc.org/abstract/ MED/1545559

12. Perez A, Gredilla E, de Vicente J, Navarro R, Gilsanz F. Characteristics and quality of intra-operative cell salvage in pediatric scoliosis surgery. Rev Esp Anestesiol Reanim. 2015 jul;63:78-83. doi: 10.1016/j.redar.2015.05.008

13. Feltracco P, Brezzi M, Barbieri S, Galligioni $H$, Milevoj M, Carollo C, et al. Blood loss, predictors of bleeding, transfusion practice and strategies of blood cell salvaging during liver transplation. Word J Hepatol. 2013 Jun;5(1):1-15. doi: 10.4254/wjh.v5.i1.1

14. Montúfas FE, Madrid CA, Villa JP, Díaz LM, Vélez JD, Vega J, et al. Coagulase-negative Staphylococcus bacteremia with vancomycin minimum inhibitory concentrations $\geq 2$. Infectio. 2016 Mar;20(1):3-8. doi: 10.1016/j.infect.2015.05.001

15. Cross MH. Autotransfusion in cardiac surgery. Perfusión. 2001 Sep;16(5):391-400. doi: $10.1177 / 026765910101600509$

16. Zhanel GC, de Corby M, Adam H, Mulvey MR, McCracken M, Lagacé $P$, et al. Prevalence of antimicrobialresistant pathogens in Canadian hospitals: results of the Canadian Ward surveillance study (CANWARD 2008). Antimicrob Agents Chemother. 2010 Nov;54:4684-93. doi: 10.1128/AAC.00469-10

17. Wisplinghoff $H$, Bischoff $T$, Tallent $S M$, Seifert $H$, Wenzel RP, Edmond MB. Nosocomial bloodstream infections in US hospitals: Analysis of 24.179 cases from a prospective nationwide surveillance study. Clin Infect Dis. 2004 Aug;39:309-17. doi: 10.1086/421946

18. Rogers KL, Fey PD, Rupp ME. Coagulase-negative staphylococcal infections. Infect Dis Clin North Am. 2009 Mar;23:73-98. doi: 10.1016/j.idc.2008.10.001

19. Hill GE, Frawley WH, Griffith KE, Forestner Minei JP. Allogenic Blood Transfusion Increases the Risk of Postoperative Bacterial Infection: A Meta-analysis. J Trauma. 2003 May;54:908-14. doi: 10.1097/01. TA.0000022460.21283.53

20. Rohde JM, Dimcheff DE, Blumberg N, Saint S, Langa KM, Kuhn L, et al. Health care- associated infection after red blood cell transfusion: a systematic review and metaanalysis. JAMA. 2014 Apr;311(13):1317-26. doi: 10.1001/ jama.2014.2726

21. Wilson R, Numan Y, Li X, Kalia A, Raad I, Shelburne S. Invasive Staphylococcus epidermidis isolates are highly clonal and distinct from commensal strains: Time for a new paradigm in infection control? O Fórum Infec Diseases. 2017 Oct;4(1):564. doi: 10.1093/ofid/ofx163.1475 
22. Cordes E, Jacob C, Loehrke M. A case of native Staphylococcus epidermidis endocarditis with cardiac abscess formation. [Internet]. 2017 Sept [cited Oct 2, 2017];195:19-27. Available from: https://scholarworks. wmich.edu/medicine_research_day/95/

23. Vicent L, Bouza E, González H, Muñoz P. Prognostic implications of a negative an echocardiography in patients with infective endocarditis. Eur J Int Med. 2018 Jun;52:408. doi: 10.1016/j.ejim.2018.01.033

24. Alcaraz B, Rojano R, Giner JA, del Amor MJ, Jiménez R, Gutiérrez $R$, et al. Endocarditis nosocomial: un problema creciente. Análisis de casos en un hospital general. Cir Cardiovas. 2018 En;25(1):1-72. doi: 10.1016/j. circv.2017.12.026

25. de Cueto M, del Pozo JL, Franco F, Marín M. Microbiological diagnosis of medical device-associated infections. Microb Clin. 2016 Dec;34(10):655-60. doi: 10.1016/j.eimc.2015.02.012

26. Kloos WE, Bannerman TL. Update on clinical significance of coagulase-negative staphylococci. Clin Microbiol Rev. 1994 Jan;7:117-40. doi: 10.1128/cmr.7.1.117

27. Shields B, Tschetter A, Wanat K. Staphylococcus simulans: An emerging cutaneous pathogen. JAAD Case Rep. 2016 Nov;2(6):428-9. doi: 10.1016/j. jdcr.2016.08.015

28. Boix L, Dietl B, Calbo E, Xercavins M, Martínez PM, Lanz J, et al. Riesgos de infección de dispositivos intracardiacos en pacientes con bacteriemia. Rev Cir Cardiovasc. 2019 Abr;26(2).126. doi: 10.1016/j.circv.2019.01.037

29. Varela L, López-Menéndez J, Navas E, Moya JL, Centella T, Fajardo E, et al. Reinfección tras tratamiento quirúrgico de la endocarditis infecciosa. Análisis de riesgos competitivos. Rev Cir Cardiovasc. 2019 Abr;26(2):126-7. doi: 10.1016/j.circv.2019.01.038

30. Loureiro J, Fernández N, Pijuan A, Dos L, Subirana $\mathrm{T}$, González $\mathrm{T}$, et al. Infective endocarditis in adult patients with congenital heart disease. Experience from a reference center. Enferm Infecc Microbiol Clin. 2016 Dec;34(10):626-32. doi: 10.1016/j.eimc.2016.01.004 31. Ahn SM, Lee JH. Perioperative blood management: Pros and cons of ANH and cell salvage. Hanyan Med Rev. 2018 Mar;38(1):27-37. doi: 10.7599/HMR.2018.38.1.27 32. Sikorski RA, Rizkalla NA, Yang WW, Frank SM. Autologous blood salvage in the era of patient blood management. Vox Sang. 2017 Aug;112(6):499-510. doi: $10.1111 /$ vox.12527
Received: Jun $25^{\text {th }} 2019$

Accepted: Apr 20 th 2020

Associate Editor:

Rosalina Aparecida Partezani Rodrigues

Copyright $(92020$ Revista Latino-Americana de Enfermagem This is an Open Access article distributed under the terms of the Creative Commons (CC BY).

This license lets others distribute, remix, tweak, and build upon your work, even commercially, as long as they credit you for the original creation. This is the most accommodating of licenses offered. Recommended for maximum dissemination and use of licensed materials. 